\title{
Problems and Ways of Improvement of Tax Instruments as a Factor in the Growth of Tax Opportunities Territories
}

\author{
Khaibat Magomedtagirovna Musaeva ${ }^{1}$, Arslanbekova Aminat Zaidullaevna ${ }^{1} \&$ Alieva Elmira Bashirovna ${ }^{1}$ \\ ${ }^{1}$ Federal state educational institution of higher professional education "Dagestan state University", Makhachkala, \\ Republic of Dagestan, Russian Federation \\ Correspondence: Khaibat Magomedtagirovna Musaeva, Federal state educational institution of higher \\ professional education "Dagestan state University", 367000, Makhachkala, Gadjieva street 43 "a", Republic of \\ Dagestan, Russian Federation. E-mail: Xaibat27@rambler.ru
}

Received: February 29, 2015 Accepted: April 20, 2015 Online Published: July 30, 2015

doi:10.5539/ass.v11n19p290 URL: http://dx.doi.org/10.5539/ass.v11n19p290

\begin{abstract}
The current state of financial security of the Russian Federation involves the creation of an institutional environment conducive to more effective management of territories. The task of balancing budgets territories in the background unstable geopolitical situation determines the priority growth of own tax revenues, increasing the tax potential of territories and the efficiency of its use by improving tax competitiveness. The main objective of the study-appreciation of the issues and identify ways to improve the tax instruments as a factor in strengthening the capacity of the tax and tax growth opportunities of the Federation. The study assessed the problems of tax federalism in the Russian Federation at the present stage. The causes of the complexity of tax allocation between budget levels under specific socio-economic development of Russia. Studied methods of decentralization of tax revenues used in foreign countries with a federal system, in terms of applications in the Russian Federation. The methods and problems of objectivity of the evaluation of the tax potential of territories. A refined method of estimating the tax potential of the Federation, based on the application of the correction factor, and thus increasing the quality and take into account the features of the regions with a low level of own tax revenues. The expediency of any tax competitiveness of territories in the formation of the tax revenues of their budgets in order to conduct a fair policy of redistribution of financial resources to re-between levels of the budget system. Formulated a set of scientific-practical recommendations aimed at improving the most mobile tax instruments of economic regulation areas in modern conditions
\end{abstract}

Keywords: tax tool, tax federalism, tax opportunities, tax potential, tax incentives, improving

\section{Introduction}

In modern conditions the preservation of the integrity and unity of the state, ensuring its economic stability, financial security and manageability depends on the solution of questions of the optimum ratio of the income of the Central, territorial and local budgets. It is known that the Russian state is an asymmetric Federation. However, the asymmetry of Federation does not mean deviation from the principles of a Federal state. In this case, compliance with the principles of a Federal states-a key part of preserving the integrity and unity of the country.

At the present stage of the development of the Russian Federation there is the need for building the real fiscal federalism, and it is important to ensure a fair balance of interests of the Centre and the subjects of the Russian Federation with a view to ensuring the integrity of the state. Sharp regional differences prevent taking advantage of decentralization of the budget system. The persistent imbalance in highly subsidized regions reduces budget responsibility. The regions that are relatively prosperous due to "natural" causes continue to benefit in the competition for economic activity. Territorial social differences are becoming stronger, which in turn leads to the disintegration of the economic space, etc. At the same time decentralization of tax revenues is still high.

The issues concerning increasing the efficiency of the tax regulation of the economy of the Russian Federation and its regions are in the spotlight of the following Russian economists: L. L. Igonina (2012), Gorskii (1999), L. P. Goncharenko (2010), I. A. Maiburov (2014), D. G. Chernik (2010), M. R. Pinskaya (2010), and others.

Despite the importance and significance of the research that has already been conducted, some theoretical and practical aspects of increasing the efficiency of tax instruments are still not adequately analyzed. In the scientific literature the 
possibilities of an increase in tax revenues due to tax stimulation of social and economic activity of the regions, the legalization of shadow income and an increase in taxable capacity were investigated very superficially, the problems related to building the real fiscal federalism still exist.

Tax regulation of the economy of the developed countries in the early $21^{\text {st }}$ century is based on the use of the achievements of such schools as the Keynesian one, the theory of supply-side economics, and the public choice theory. The domination of the public choice theory in most European countries (the necessity for financing public goods) can be considered to be the key tendency, the theory of supply-side economics being used for stimulation of investment and innovative activity of the subjects of the economy. The postulates of the Keynesian theory were relegated to the background until the financial crisis of 2008-2009. However, in the conditions of the financial crisis the problem related to the necessity for formation of tax policy with regard to cyclical fluctuations became urgent again. The lingering debt crisis that swept the European countries at the beginning of 2011 and the need for a significant increase in the budget revenues with a view to financing the accumulated debt obligations also require revisiting and improving of the tax policy followed by industrial countries.

Their main competitors in the scientific world are the works of the following foreign scientists who conduct research into tax regulation of income of territories: P. Valente (2012), E. Bodie (2009), G. Tullock (1988), Musgrave (2009), S. Brown (2012).

\section{Materials and Methods}

The improvement of the methods and the ways of distribution of taxes between the levels of the budgets is closely connected with the need for accurate and objective assessment of taxable capacity. The assessment of taxable capacity should be carried out for each type of taxes at the regional level, the economic specifics of the region being taken into account. There are several approaches to the assessment of the taxable capacity of a region. The calculation of taxable capacity is an important part of the budget process, and the regional authorities are absolutely right when they consider this indicator to be important in their regulatory framework. The analysis of recent publications has shown that different authors have different approaches to the assessment of the taxable capacity of a region. It should be noted that calculation made on the basis of the uniform efficient factor of the tax base determines the representative tax rate which shows the amount of taxes actually received by the budget from one unit of the tax base, and the representative tax rate is calculated as the ratio of actual tax revenues to the tax base. Data about the sizes of tax bases are provided by the taxing authorities. Rates are determined as national average ones. The use of average rates allows of calculating the amount of revenues collected by the region in case of making fiscal effort of the average level. Taxable capacity is calculated with the help of adding the tax bases for all taxes in the region and the national average rates for them.

In our opinion, the use of the national average rates in a representative tax system does not work correctly due to the peculiarities of the economic development of the regions. The majority of the subjects of the Russian Federation are short of their own financial resources.

The second group of methods employed by S. I. Islyamutdinov is based on regression analysis (Islyamutdinov, 2007). Key characteristics of these methods include tax and fee revenues, arrears of taxes, and decreased tax revenues due to granted tax benefits, as well as macroeconomic indicators. The differences between the additive and regression methods lie in the form of connection between resource and performance characteristics of taxable capacity and the degree of disaggregation of the original data. Almost all works suggest using a linear regression model which has the following generalized form:

$$
\mathrm{TC}=\mathrm{a}_{0}+\operatorname{ajxj}+\mathrm{a}_{2} \mathrm{x}_{2}+\ldots+\mathrm{a}_{\mathrm{c}} \mathrm{x}_{\mathrm{c}}+\mathrm{e}
$$

Where $\mathrm{a}_{0}$ is an absolute term;

aj $a_{2}, \ldots a_{c}$ - coefficients of the regression equation;

$\mathrm{xj} \mathrm{x}_{2}, \ldots \mathrm{x}_{\mathrm{c}}$ - factors of the taxable capacity of a region that characterize the tax base;

e - a stochastic component that integrates the influence from unaccounted factors.

The result of the calculations of this regression equation is the theoretical value of tax revenues (tax revenues per capita) based on the average level of use of tax resources and the average tax effort of local authorities, which is considered to be taxable capacity. "Observation points" in this model are presented by the territories included in the analyzed range.

When used for the assessment of the taxable capacity of the territory (region), the regression method has a number of advantages over the additive method:

- Firstly, it requires much less information, the main sources of which are published official statistic data of the subjects of the Russian Federation and municipalities. 
- Secondly, the estimates of tax obligations made with the help of this method, form an integrated system of indicators included in the model, and, therefore, are commensurable.

- Thirdly, this method allows of making prediction calculations for the short and medium time intervals.

- Fourthly, in contrast to the additive method that has cumbersome formulae, the application of this method implies the construction of a relatively simple model.

However, the regression method has its own formal restrictions that may prevent its application in practice. Among them there are the following ones:

- The results received with the help of this method are very sensitive to the homogeneity and composition of the original range of the territorial entities. As the method is based on averaging of the parameters of the formation and use of tax obligations of a subject of the federation, the necessity for ensuring reliable and stable patterns between the average values of the performance and factor characteristics is an important condition for the manifestation of correlations and, therefore, the applicability of regression models. This requires the qualitative homogeneity of the studied range;

- The need for the conformity of distribution of territories with the performance and factor characteristics, the normal law of probability distribution is an essential condition for the applicability of the regression method, which ensures the reliability of the received results (Sidorova \& Bor, 2013).

In case of non-compliance with these requirements, the regression models mentioned above will have unsatisfactory qualitative characteristics, and the results of calculations will be of little value and practical use.

The last group is represented by the structural method of determining the taxable capacity of a region. The method was developed by the Ministry of Finance of the Russian Federation in the context of building a system for the distribution of subsidies from the Federal Fund for Financial Support of the Subjects of the Russian Federation. The official annual calculation of gross tax resources of the subjects of the Russian Federation (hereinafter referred to as the "GTR") and indices of their taxable capacity (hereinafter referred to as the "ITC") is made on its basis. Both indicators serve as quantitative estimation of the taxable capacity of the regions of the country, but there is one key difference between them: the GTR are the absolute value of the potential tax revenues of the consolidated budgets, calculated per capita, and the ITC are relative assessment of the ability of the regional economy to generate these tax revenues as compared with the national average value.

Most scientists use information that is necessary for assessing the taxable capacity of a region as a classification criterion. For example, E. B. D'yakova divides methods into four groups: the first one uses macroeconomic indicators as incoming information; the second group consists of methods of assessment based on the transformed data from the official tax forms; the third group includes methods based on correction of the payments actually collected in the region during the base year; the fourth group is represented by one way of assessing taxable capacity - with the help of the method of a representative tax system, which is based on using information about the average level of tax effort of local authorities (D'yakova, 2002).

This classification was improved by N. N. Kunitsyna and V. V. Roshchupkina. They divided all assessment methods into four groups:

- Methods of assessment with the use of economic income indicators;

- Methods of assessment based on the construction of a representative tax system;

- Methods of assessment based on data from tax forms and adjustment of sums of actually collected taxes;

- Methods of assessment with the use of the taxable capacity index (Kunitsyna \& Roshchupkina, 2008).

\section{Results}

Thus, the study of methods for the assessment of taxable capacity of a region showed their great variety. However, for the moment there are no methods that would take into account the specifics of development of the regions and the structure of their taxable capacity.

For more accurate assessment of the taxable capacity of a region it is advisable to use an approach based on the use of a representative tax system, the correction coefficient being taken into account. Improvement of the accuracy of methods used for calculation of tax capacity is necessary in the first place for the regions with a low level of their own tax revenues, such as the Republic of Dagestan.

Explanation of the economic sense of the correction coefficient (k): the representative tax system was created to simplify calculations. The coefficient kj showed the average level of collection of the main types of taxes, which was calculated for all regions of the country. However, this approach is not absolutely correct because of the 
large differences between the regions of the Russian Federation. That is why it is advisable to use not the national average coefficient $\mathrm{kj}$, but the average one for the cluster consisting of regions with approximately the same structure and amount of tax revenues. The quantitative estimation of the coefficient is based on the paired regression equation, where tax revenues are a dependent variable and the gross regional product is an independent one.

In further calculations we will use the system containing taxes received by the consolidated budgets of the subjects of the federation in 2013: tax on the profit of organizations, personal income tax, excise taxes, tax on the assets of organizations, vehicle tax, personal property tax, land tax. All values are calculated per capita.

The following regions were included in the first cluster according to the results of clustering conducted with the help of method average $\mathrm{k}$ values for the main taxes received by the consolidated budgets of the subjects of the RF for three clusters: the Nenets Autonomous Area, the Khanty-Mansi Autonomous Area, Moscow, the Yamal-Nenets Autonomous Area. The second cluster includes the Moscow region, the Republic of Komi, the Vologda region, the Murmansk region, St. Petersburg, the Sverdlovsk region, the Tyumen region, the Krasnoyarsk Territory, the Republic of Sakha, the Kamchatka Territory, the Magadan region, the Sakhalin region, the Chukotka Autonomous Area. The rest of the regions were included in the third cluster.

It should be noted that the Republic of Dagestan falls into the third cluster. Therefore, further calculations were made for this cluster.

The results of the regression analysis were used for obtaining correction coefficients for taxes calculated for the Republic of Dagestan. The calculations showed that there were revenue reserves for excise taxes and tax on the profit of organizations, land tax, and personal property tax. The amount of other taxes collected in the region is larger than the average one for the cluster. Then the actual tax revenues should be adjusted by the calculated coefficients with a view to obtaining the value of the taxable capacity.

Using the proposed methods that include economic-mathematical ones will significantly improve the quality of assessment of the taxable capacity of a subject of the Russian Federation. This approach, in turn, will ensure objectivity in the course of tax planning and in inter-budget relations, will allow of taking into account the seasonality in tax revenues, and will ultimately lead to improvement of the efficiency of tax planning.

\section{Discussions}

In terms of international economic and political instability, acts of anti-Russian sanctions increases the need for internal reserves of economic growth of the Russian state through the creation of conditions for development of financial and economic potential of its regions. At the present stage of the Russian Federation there is an urgent need to improve regional policies, especially the creation of economic and financial incentives for self-development and economic growth areas. Improving efficiency in the management of subjects of Federation can be achieved by improving tax policy as being essential actual realization of the principles of real fiscal in the country.

Implemented in the Russian model of fiscal federalism is unique, that is largely due to the accession of a large number of subjects of the Russian Federation (especially after the integration of Crimea and Sevastopol), significantly different in terms of socio-economic development. In the process of implementation of the principles of fiscal federalism in terms of the Russian Federation must take into account not only socio-economic but also historical, climatic, demographic, ethnic and national differences. The implementation of the principles of fiscal federalism is currently complicated by the consequences of the financial and economic crisis and the continuation of anti-Russian sanctions. In the current environment, an important task of the state is to build such a model of differentiation and distribution of taxes between levels of budgets, which on the one hand, aim to eliminate significant differences in the economic development of subjects of Federation, on the other hand, would maintain incentives for self-development areas.

Foreign scientists pay much attention to the problems related to fiscal federalism. In particular, L. Ong writes about kid-glove methods of financial equalization in China (Ong \& Lynette, 2011), western scientists (Breul \& Madies, n. d.) point out the policy of redistribution and constraints on government expenditures, carried out in France and Germany (Marie-Laure, 2007).

Famous Russian academician D. A. Tatarkin believes that "fiscal federalism is a complex social-economic phenomenon that includes organizational and technical actions related to the formation and distribution of centralized and decentralized state funds, as well as the range of specific economic relations that are controversial by nature and reflect peculiarities of interaction between all participants who generate and implement the tax process" (Tatarkin, 2013). 
The main purpose of constructing a real fiscal federalism in the Russian Federation is to ensure the integrity of government, stability and sustainability of the socio - economic development based on the needs of the centre, regions and municipalities, achieved through effective redistribution of tax revenues between levels of the budget system. In our opinion, the real fiscal federalism involves not only the separation and the distribution of Federal legislative acts of taxes between different levels of government, but also providing tax incentives to subnational (regional and local) authorities within a single fiscal space in the country. This is the fullness of the concept of fiscal federalism (Musaeva, 2012).

The world practice knows four main approaches to solving the problem related to the delimitation and distribution of taxes between budgets: cumulative (one tax rate includes rates of all levels of authorities); normative (the proportional distribution of taxes between the budgets of different levels according to the rates, in percentage; distributive (tax revenues are accumulated on one account or in one fund with further redistribution between the links of the budget system); fixed (delimitation and "fixation" of taxes to the levels of administration in accordance with the principles of fiscal federalism).

The necessity for the practical application of different methods of distribution of taxes between budget levels arises not only due to the peculiarities of the territorial structure of the state, but also because of a multiplicity of taxes and their impact on factors of production. R. Musgrave wrote about this: "Different taxes will have different effects on the rate of saving and investment and thereby on capital formation. As the rate of capital formation is increased or reduced, factor earnings and hence incomes before tax will be affected" (Musgrave \& Bor, 2009).

At the present stage in the Russian state separation and the distribution of taxes between the Federal, regional and local budgets are based on a combination of fixed, distributing and regulatory methods. Practice shows that used in the methods of differentiation and the distribution of revenues between levels of the budget system are not effective because they contribute to the increase of deductions from Federal taxes, do not stimulate the regions and municipalities to increase the tax potential and the collection of its own taxes.

During 2008-2014 the structure of tax revenues of the budget system of the Russian Federation changed in different directions under the influence. In particular, the period 2008-2010 was accompanied by an increase in the proportion of territories in the tax revenues of the consolidated budget. In 2011 and 2014 have any reverse the trend of declining regional share of tax revenue that was associated, first, with the growth of Federal budget revenues from foreign economic activity, and secondly, with a low rate of economic growth and the emergence of new signs of economic downturn, which adversely affected the revenue of the tax on profit of organizations. Real GDP growth fell from 4.3\% in 2011 to $3.2 \%$ in 2014, income tax expense in 2014 compared to 2011 decreased by $3.9 \%$ to $3.1 \%$ of GDP.

Table 1. Gross domestic product (GDP) and tax revenues konsolidirovannogo budget of subjects of the Russian Federation in 2008-2013

\begin{tabular}{lllllll}
\hline Indicators & 2008 & 2009 & 2010 & 2011 & 2012 & 2013 \\
\hline Gross domestic product, bln. rud. & 26781.1 & 32987 & 41276.8 & 38807.2 & 45172.7 & 54585.6 \\
The growth rate of GDP of the previous year, \% & 123.9 & 123.2 & 125.1 & 94.5 & 116.4 & 120.8 \\
The tax revenues of the consolidated budgets of & 7784.2 & 9341 & 10987.4 & 7576.6 & 8443.5 & 11592.6 \\
the RF subjects, bn. rud & 29.07 & 28.32 & 26.62 & 19.52 & 18.69 & 21.24 \\
The share of taxes in GDP, \% & & &
\end{tabular}

Source: http://www.r05.nalog.ru/statistic

As can be seen from Table 1, the share of tax revenues of the consolidated budget of the Russian Federation's GDP is relatively stable and does not exceed $30 \%$, while the level of developed foreign countries. At the same time it should be noted a downward trend in the share of GDP pereraspredelyaemoy through the tax system of the Russian Federation with $29.07 \%$ in 2008 to $18,7 \%$ in 2012.

Reduced income tax profit was largely due to the introduction of the institution of the consolidated group of taxpayers, increase federal authorities tariffs of natural monopolies, excluding the opinions of the Russian Federation, which led to higher costs organizations reduce the profitability of production, resulting in a reduction of the tax base and reduce the amount of income tax on profit organizations.

Unbalanced regional and local budgets, over-accumulated tax powers at one level, poor institutional environment 
that is not appropriate for creating a favorable tax climate for the investors are the consequences of today's Russian regional and municipal finance management system operations.

These circumstances cause the appropriateness of accounting tax competitiveness of territories in the formation of the tax revenues of their budgets in order to conduct a fair policy of redistribution of financial resources between different levels of the budget system and counteract the formation of dependency attitude among representatives of regional authorities.

At the present stage one of the difficult methodological problems is to ensure the equity in the delimitation of "inflation" taxes between the and the budgets of the central subjects of the federation. These revenue sources include such taxes as VAT, excise taxes, tax on the profit of organizations, personal income tax. In our view, the terms of Russian legislation is necessary to provide a mechanism for securing a permanent or long-term basis of the proceeds of "inflation" taxes to the budgets of subjects of the Federation.

In the Russian Federation there are sharp differences between the regions in terms of economic development that is why it is advisable to differentiate the rates of deductions from regulatory taxes in different by region, using uniform criteria. This approach will allow the normative method to perform a regulatory function. Though the principle of substantiation of the sizes of the tax revenues budgets of the territory is uniform, the rates of the deductions from regulatory taxes in the regional budgets may be different, differentiated. The unity should be reflected in the main thing - equal opportunities of the regions, not in the same rates and norms of deductions from regulatory taxes.

The goal of balancing territorial budgets in an unstable geopolitical situation presupposes that the priority is to increase the number of own revenue sources within regional and local budgets. Given the fact that tax revenues prevail within the local budgets, the issue of territorial tax potential increase and tax potential use efficiency increase by improving the tax competitiveness moves to the forefront.

The scientific value of resolving the issue of increasing the territorial tax competitiveness lies in the theoretical understanding of the significance of involving taxpayers in the resolution of issues that have national and territorial dimensions to them. This allows us to form a theoretical basis for ensuring an optimal provision of public goods through increasing the responsibility of government authorities for their performance in their territories. Efficient resolution of the issue of increasing the territorial tax competitiveness makes it possible to build a basis for improving the current tax incentive provision mechanisms aimed at attracting investors to a particular territory thus increasing the tax potential of the regions and municipal entities. Substantial scope for growth in the budget revenues is the reduction in the shortfall in tax revenues by way of reducing the amount of tax benefits provided.

As a result of granting various benefits, the consolidated budget of the Russian Federation loses, according to different estimates, from $45 \%$ to $55 \%$ of all tax payments. Under the current circumstances, searching for a reasonable balance between tax benefits and the need for improving their efficiency continues to be a pressing problem. The improvement of the tax system with the help of the elimination of benefits that are not effective in social and economic terms, but give a considerable advantage to individual taxpayers and opportunities for tax avoidance is a priority. However, elimination of benefits as well as the introduction of new benefits should entail preliminary examination of their practicability.

There is the need for transformation of benefits with a view to strengthening their stimulating effect on economic development, securing effect and increasing social return. The analysis of the legislative acts of the Russian Federation shows that no more than 15 tax benefits out of more than 200 ones that exist at present are aimed at stimulation of investment and innovative activities. The applied system of granting tariff preferences doesn't mesh with the priorities of the state, in promoting investment and innovation, despite the fact that the share of high-tech products in the Russian Federation in the international market is only $2 \%$.

One of the most important problems related to the growth of the financial component of the region is identification and solving of problems connected with large-scale tax evasion and, therefore, ones related to the expansion of the tax base. This problem can be solved by implementing a set of systematic recommendations, such as improving budget and tax legislation, strengthening the incentive component of the tax mechanisms, increasing the efficiency of tax administration and promoting tax literacy of the population. This problem is especially urgent for the regions of the North Caucasian Federal District due to a low level of self-sufficiency and insufficiency of financial resources for the full implementation of priority projects and programs, accelerated modernization of the economy.

The population's level of tax literacy plays an important role in ensuring the receipts of tax revenues by the budget system. It should be seen as an integral part of the economic and legal literacy. In order to ensure the effective management of the tax system, the regional authorities should pay special attention to the promotion of 
tax literacy of the population, especially the younger generation. The level of tax literacy of the population, the relations between a taxpayer, a state and taxing authorities, the psychological readiness of a taxpayer have an impact on the awareness of the obligation to pay taxes.

The "state-taxpayer" problems are given special attention in the developed countries; the taxing authorities, education authorities and mass media try to cope with it. In particular, in Japan, the USA, Canada and other countries children get training in the basics of taxation when they go to kindergarten, and it continues at school. There are special contests for children (an essay contest in Japan), thematic TV and radio programs (in Germany). Taxpayers receive free instruction manuals and guides with explanations about filing a tax.

\section{Conclusion}

After the main problems preventing the subjects of the Russian Federation from effectively regulating their own economies having been identified, the following ways of solving them are proposed:

- The main tax methods of regulation of the economies of the subjects of the RF are employed by the federal authorities. Due to the large territory and different levels of the economic development of the subjects of the Russian Federation the possibilities for taking into account the specifics of each subject of the Russian Federation are reduced;

- Centralization of tax revenues: most of the tax revenues of the subjects of the RF are deductions from federal taxes; they are received by the federal budget and then redistributed between the subjects of the Russian Federation. In our opinion, the list of regional and local taxes may be extended, for example, by making personal income tax and excise taxes regional ones;

- The powers of the Russian Federation's subnational authorities over the introduction of regional and local taxes are very limited. All determinant elements of taxation are specified in the federal tax legislation, and the regional and local authorities (article 12 of the Russian Tax Code) are entitled only to specify the tax rate within the limits set by the federal laws, to add benefits to the list, to determine the procedure and time limits for paying taxes. Sufficient autonomy in the fiscal policy implementation allows subnational governments to determine the scope and quality of public services in accordance with the needs of the population within the territory. Financing a substantial part of the costs by using own tax revenues contributes to the transparency of spending;

- The subjects of the Russian Federation do not use their powers efficiently. The main tax methods used by the subjects of the Russian Federation are tax rates and tax benefits. Both methods should be applied at the same time. Such an instrument as tax rates is used by the subjects of the Russian Federation, as a rule, for investment purposes. At the same time, tax benefits are generally social by nature and designed to alleviate the tax burden for socially unprotected citizens. However, tax benefits can also encourage investment activity;

- At present the Russian Federation has no uniform mechanism of granting benefits, which would determine the objectives, priorities and types of benefits, interrelated and complementary across all tax types. This causes the following situation: the benefits granted within the incidence mechanism of some taxes lose their stimulating effect, weaken the effectiveness of the tax policy in general;

- Popularization of tax legislation should necessarily become part of national and regional programs aimed at the development of the legal literacy of the population, a condition that ensures the application of the principle of voluntary observance of tax laws as a target that tax reforms are aimed at.

Increasing the tax competitiveness of territories on the basis of a systematic approach to the implementation of a set of recommendations and measures to improve tax tools and mechanism of tax administration, improve the implementation of regional tax potential by limiting the informal sector, will strengthen the financial base of regional and local budgets, which is a condition for State security. Thus, the results of the study will contribute to the solution of one of the tasks of the priority areas of science, technology and engineering in the Russian Federation (Presidential Decree of July 7, 2011 №899).

The need for integrated solutions outlined above issues require in-depth studies of the problem, increase the efficiency of the tax regulation of economy of the territories in the world and in the Russian Federation. A special place in the study recommends be given to sovershenstvova-of indicators to measure the tax capacity and competitiveness regions.

\section{Acknowledgements}

Work carried out in the framework of implementation of the state task \# 2014/33 Education and Science of Russia in the field of scientific work in the direction of the project "Integrated study of problems of countering the ideology of extremism and terrorism in Dagestan", section "The legalization of the informal sector as a growth 
factor of the tax capacity and improving the region's security."

\section{References}

Bodie, E., \& Merton, R. (2009). Finances. Williams Publishing House, Moscow.

Brown, S., \& Gale, W. (2012). Tax reform for growth, equity, and revenue (pp. 5-12). Urban -Bookings Tax Policy Center.

Chernik, D. G. (2010). Competent tax policy - an incentive and support for business. Gramotnaya nalogovaya politika - stimul i podderzhka dlya biznesa. Nalogovyi vestnik, 1,9 .

D'yakova, E. B. (2002). Formation and assessment of the taxable capacity of a region (evidence from the Volgograd region): Dissertation (p. 84). Formirovanie i otsenka nalogovogo potentsiala regiona (na primere Volgogradskoi oblasti): dis... kand. ekonom. Nauk. Volgograd.

Goncharenko, L. P. (2010). Revisiting the conceptual framework of tax administration. K voprosu o ponyatiinom apparate nalogovogo administrirovaniya. Nalogi i nalogooblozhenie, 2, 17-24.

Gorskii, I. V. (1999). Taxable capacity in the the mechanism of inter-budget relations. Nalogovyi potentsial v mekhanizme mezhbyudzhetnykh otnoshenii. Finansy, 6, 27-35.

Igonina, L. L. (2012). Development of tax potential of the regions in the determinants of modernization processes ["Development of tax potential of the regions in the determinants of modernization processes. Taxes and Financial pravo, 3, 197-202.

Islyamutdinov, S. I. (2007). Taxable capacity of a territory: Methodological aspects of formation and use: Dissertation. Nalogovyi potentsial territorii: Metodologicheskie aspect formirovaniya i ispol'zovaniya: dis... kand. ekonom. Nauk. Samara.

Kunitsyna, N. N., \& Roshchupkina, V. V. (2008). Problems related to assessment of the taxable capacity of a region. Problemy otsenki nalogovogo potentsiala regiona. Nalogi i nalogooblozhenie, 2(59), 49-53.

Maiburov et al. (2014). Tax benefits (p. 234). Theory and practical application. Nalogovye l'goty. Teoriya i praktika primeneniya. YUNITI-DANA, Moscow.

Marie-Laure, B., \& Taugourdeaux, M. T. (2007). Emmanuelle Fiscal Federalism and Soft Budget Constraint: Does the nature of public spending matter? Journal by University of Paris West; Nanterre la Defense, Economics Working Papers, 16, 1-17.

Musaeva, K. M. (2012). Formation and development of fiscal federalism in the RF: problems and prospects. Formirovanie i razvitie nalogovogo federalizma v RF: problemy i perspektivy. Nalogi i nalogooblozhenie, 4, 45.

Musgrave, R., \& Musgrave, P. (2009). Public Finance in Theory and Practice (p. 319). Business Atlas, Moscow.

Ong, L. H. (2011). Fiscal federalism and soft budget constraints: The case of China. International Political Science Review, 33(4), 454-474.

Pinskaya, M. R. (2010). Harmonization of tax relations in a federal state: Dissertation abstract (p. 23). Garmonizatsiya nalogovykh otnoshenii $\mathrm{v}$ federativnom gosudarstve: Avtoreferat na soiskanie uchyonoi stepeni doktora ekonomicheskikh nauk. Spetsial'nost': 08.00.10. Moscow.

Sidorova, E. N., \& Tatarkin, D. A. (2013). Financial potential of regions and their social and economic attractiveness (p. 385). Finansovyi potentsial regionov i ikh sotsial'no-ekonomicheskaya privlekatel'nost. Institute of Economics, The Ural Branch of Russian Academy of Sciences [Institut ekonomiki UrO RAN], Ekaterinburg.

Tatarkin, A. I. (2013). Russian fiscal federalism as the precursor of economic instability: Problems and ways of improvement (Vol. 1, No. 60, p. 179). Rossiiskii nalogovyi federalizm kak predvestnik ekonomicheskoi nestabil'nosti: problemy i puti sovershenstvovaniya. Nauchnyi vestnik Natsional'nogo universiteta gosudarstvennoi nalogovoi sluzhby Ukrainy (ekonomika, pravo), Irpin.

Tullock, G. (1988). The New World of Economics (2nd ed.).

Valente, P. (2012). Enhanced Cross-border Cooperation against Aggressive Tax Behaviours. An Outlook on International Tax Initiatives. The $5^{\text {th }}$ European Conference on Tax Advisers' Professional Affairs, London.

\section{Copyrights}

Copyright for this article is retained by the author(s), with first publication rights granted to the journal.

This is an open-access article distributed under the terms and conditions of the Creative Commons Attribution license (http://creativecommons.org/licenses/by/3.0/). 